\title{
THE LEFT HANDS OF LOVERS
}

\author{
Strong connection.
}

\section{BY EMILY ECKART}

$\mathrm{T}$ he deactivated robots were corralled upright in cages. I navigated the rows under the red light, searching for the only face that mattered. She was in the back. Her shapely features stood out; the other robots had been designed ugly on purpose.

"Rosalind," I whispered, foolishly expecting a response. But there was only my breath and the soft whine of the lights: no more of her pleasant hum, reassuring as a heartbeat. She was fully deactivated, her memory chip wiped clean.

Even in deactivation, her face held that mysterious semi-smile. I realized it was her default expression - not, as I had believed, a smile just for me.

I met Rosalind the week after the terrorists fled, when the city still gleamed with blood and broken glass. The commander introduced the robots to our unit. They resembled both sexes and all races, but were uniformly ugly - eyes too close together, odd-shaped noses, warts.

"You'll use these robots for inspecting buildings abandoned by the terrorists," he said. "Their exteroceptive sensors can detect the vapours of eight different explosives, as well as chemical weapons like nerve agents. That way we don't risk human lives." He assigned each soldier a robot. When he got to me, there was none left.

He took me aside. “There's one robot left from the previous generation. Not an ideal model, but they're too expensive to waste. We thought you could handle it."

He led me into another room. The robot was wearing jeans and a V-neck. She had skin the colour of a coffee-flavoured soy drink. Her eyes were wide and green.

"This is RL38501X. We ordered humanoid robots after studies showed soldiers worked best with machines that they related to. But this generation was too relatable. People got attached. Last year a man followed his robot inside a booby-trapped building and died."

The robot smiled at me. Her kind expression reminded me of my mother, who had been killed with the rest of my family in the bombing of ' 32 .

DNATURE.COM

Follow Futures:

@ @NatureFutures

f go.nature.com $/ \mathrm{mtoodm}$
"It's a machine," he said. "Think of it as it." As I directed the SmartCar to the edge of the city, RL38501X made conversation from her hermetically sealed compartment in the back.

"Are you from this area?" she asked.

"Nope. Transferred here to join the military back in '33."

"Do you like it?"

I shrugged. "Sometimes it's lonely."
She touched my prosthesis. A static shock passed between us, sharp and bright, much more vivid than the faint sensations I was used to.

"Ow!" I felt guilty as soon as her face assumed a hurt expression. I grabbed her right hand with my left. She smiled. Quietly, we watched the sun rise higher over the city.

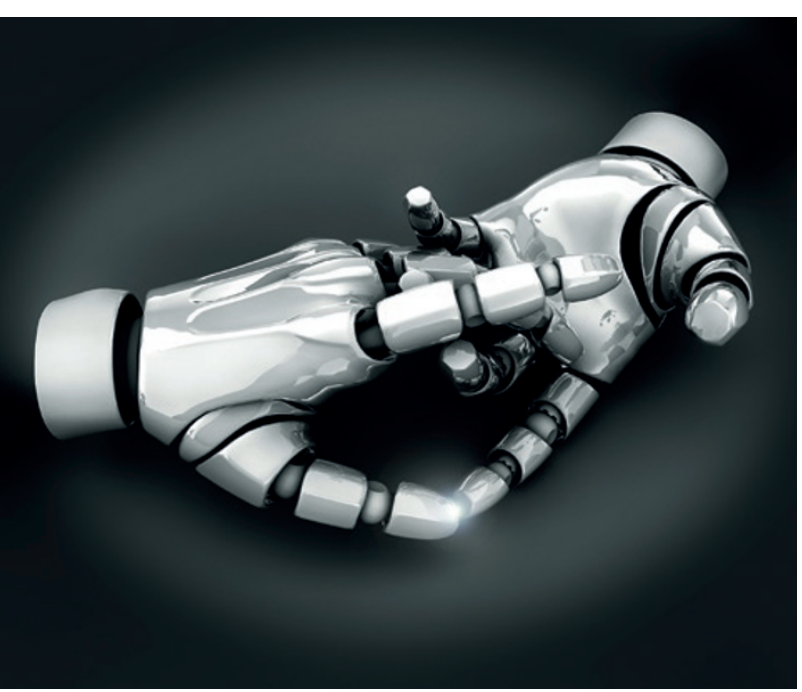

"That is sad. No one should feel lonely."

I let her out at the checkpoint. It, I reminded myself. Its job was to investigate a suspected storage facility for Novichok agent powders. As I waited, I found myself hoping she would be safe. Be safe, RL ... Who could remember that serial number? RL should signify a name, I decided. Rosalind.

While other robots got blown up or contaminated by toxic chemicals, Rosalind went months without incident. We were transferred closer to the battlefront. On our first anniversary, I drove her to the hill above the new city. We looked out over the scarred buildings, the roads strewn with litter and wreckage. In the morning light, if you forgot what it meant, the glittering debris almost looked beautiful.

"Your hand is like mine," Rosalind said. I had wondered when she'd notice. My left hand was a prosthesis. I had the same thin line on my wrist as she, the same titanium joints beneath artificial skin.

"I lost my real hand. In an accident." Fleeing my besieged hometown, I had fallen in the road. My hand was crushed by an errant SmartCar.

Rosalind furrowed her eyebrows. "What is a 'real hand'? Is this not real?"
I felt nervous about the squat concrete building Rosalind had to inspect that week. Its broken windows gaped like missing teeth in the grin of some delinquent.

As I waited, I thought about where I'd take her that night. I had been checking her out of the robot storage room a couple of nights a week, using maintenance as an excuse. So far we had listened to a Mozart symphony and watched a Truffaut film. She hadn't yet seen the stars.

I stared out the windshield, wondering when she would return. It had been longer than usual. A call came in on my earpiece.

"Your robot has been contaminated. Return to base immediately."

"Contaminated? How?"

"A new strain of bacteria engineered by the terrorists. Extremely antibiotic resistant."

"But I can't just leave - "

"Return to base immediately. Your robot will be sent to BioLabs for analysis and disposed of safely. You'll be assigned a new one tomorrow."

The disposal facility was five miles from base, but adrenaline made it feel close. I snuck into the basement and found her crammed in a cage like trash. I reached through the bars and took her dangling hand, drawing it towards me. Her silicone skin was perfect, poreless, cold.

With my right hand, I unscrewed my left prosthesis and dropped it on the floor. I unscrewed her left hand and attached it to my stump. As I walked away, my breath came shorter. Did I feel an itching in my chest, a dizziness? Would they find my body pockmarked and ridden with buboes? I did not care. Without Rosalind, I had no one.

Emily Eckart studied music and English literature at Harvard University. Her fiction has appeared in Potomac Review, Literary Orphans and elsewhere. You can read more of her work at www.emilyeckart.com. 